\title{
The principles of Natural Sequence Farming
}

\author{
John Williams
}

Natural Resources Commission, Level 10, 15 Castlereagh St,

Sydney NSW 2000, Australia

E-mail: john.williams@nrc.nsw.gov.au

\begin{abstract}
The paper outlines the four fundamental principles of Natural Sequence Farming (NSF). It explains historical changes in the Australian landscape affecting vegetation, drainage, and morphology, including the typical perched water flows. NSF management techniques are analysed as structural and non-structural and, in the opinion of the CSIRO Expert Panel, both produce manifold benefits in terms of erosive water velocities, aquifer recharge, soil structure, erosion, compaction, and pasture productivity, to name a few.
\end{abstract}

Keywords: NSF; natural sequence farming; soil function; flow regimes; groundwater recharge; erosion control; salinity control; pioneer plants; ecosystem health.

Reference to this paper should be made as follows: Williams, J. (2010) 'The principles of Natural Sequence Farming', Int. J. Water, Vol. 5, No. 4, pp.396-400.

Biographical notes: John Williams is the New South Wales Natural Resources Commissioner, and was formerly Chief of the CSIRO Division of Land and Water. He has degrees in soil physics and hydrology, was awarded the Farrer Medal for excellence in agricultural science in 2005, and is Adjunct Professor in Agriculture and Natural Resource Management at Charles Sturt University. As a founding member of the Wentworth Group of Concerned Scientists, he is engaged at the interface between science and public policy. He is also Chair of the International Scientific Reference Panel on Natural Sequence Farming.

\section{Introduction}

Natural Sequence Farming (NSF) is an agricultural system based on understanding landscape and ecological processes and implementing vegetation, land and water management practices compatible with these processes to achieve sustainability (CSIRO, 2002). It was developed by farmer Peter Andrews, on the property Tarwyn Park, in the Upper Bylong Valley, headwaters of the Hunter River catchment, New South Wales, Australia.

\section{Principles}

There are four fundamental principles that underlie the NSF system, as advocated by Andrews $(2006,2008)$.

Copyright (C) 2010 Inderscience Enterprises Ltd. 
- Restoring fertility held by nutrients and organic matter improves the biological function of soils.

- Reinstating hydrological balance increases groundwater storage in the floodplain aquifer, increasing freshwater recharge and hence reducing saline groundwater discharge.

- Re-establishing natural vegetation succession through pioneer species promotes the healthy growth of native plant communities.

- Understanding the hydrological and biogeochemical processes that drive the natural landscape system allows their management to restore ecological function.

\section{Setting}

Over modern time ( $<1000$ years), development of the landscape (drainage network and hillslope morphology, discharge of water and sediment) is contingent upon the factors of climate, vegetation, geology, relief, runoff and sediment yield. The most significant and widespread historical change to either the flow or the sediment regimes of upland rivers is an increase in sediment inputs, through increased erosion (Young et al., 2001). Discontinuous streams or gullies, such as the 'chain of ponds' and 'valley fill' types, were once widespread prior to European settlement. Under natural conditions, vegetation changes diverted flows into perched palaeo (pre-European) distributary flow paths, or from one distributary to another.

Flow regimes have changed since European settlement (Hughes et al., 2001) with increased run-off, and small headwater streams have become more defined, incised and faster flowing. The drainage or incision of streams has occurred following degradation resulting from past management practices. Flow regimes have also changed during this time because of climate variations, resulting in long periods of flows above and below the longer-term average. What were once swampy meadows with a chain of ponds have become well-connected and continuous drainage networks (Eyles, 1977). This has led to significant negative impacts on sediment load, base flows, salinity, groundwater recharge, and riparian vegetation.

\section{Benefits}

The NSF approach can achieve stream health and floodplain sustainability by the rehabilitation of a pool-riffle or chain of ponds type aquatic habitat and inundated floodplain wetlands. This enables the recreation of a distributary flow system through the use of secondary floodplain channels and in-stream diversion structures, combined with the effect of riparian vegetation changes, providing morphological complexity. The perched nature of the distributary flow system can allow the hydrostatic pressure of fresh water to prevent saline intrusion. The outcomes are raised bed levels, arrested bed and bank erosion, increased surface and shallow ground water levels, and creation of waterholes and backwaters in a pool-riffle or chain of ponds sequence. Recent findings on the NSF approach to landscape rehabilitation are being documented by Southern Cross University (SCU). 
According to the CSIRO Expert Panel Report (CSIRO, 2002), the following major environmental and agricultural issues are addressed by the implementation of NSF:

- low floodplain productivity

- elevated salt export

- salt intrusion into the root zone of floodplain soils

- channel erosion

- hillslope erosion

- low functional diversity of pastures

- poor nutrient retention in plant-soil system

- altered surface-groundwater hydrology.

As a result, the benefits of implementing NSF can be described as:

- decreased salt fluxes

- increased sedimentation

- increased shallow aquifer recharge

- decreased water velocities

- maintained high water tables

- effective subsurface irrigation

- increased pasture productivity

- increased soil organic carbon levels

- increased residence time of nutrients

- minimised soil erosion and compaction

- maintained soil structure.

\section{Features}

The implementation of NSF is evident as a combination of structural and non-structural management measures that have altered water, salt and nutrient balances, and have increased farm productivity (CSIRO 2002).

The structural measures of NSF include:

- grade-control structures in the stream line

- contour banks on the floodplain and at the hillslope-floodplain break of slope

- contour channels diverting water away from the stream line.

These structural measures provide increased residence time of water by diverting floodwaters from the stream to the floodplain, and hence increasing shallow aquifer 
recharge, and by decreasing water velocities in the channel and on the floodplain. The management of the hydrologic regime allows substantial recharge, and allows maintenance of high water tables across the floodplain.

The non-structural measures include:

- avoidance of surface (spray) irrigation

- avoidance of herbicide use

- minimal use of chemical fertilisers

- avoidance of ploughing on hillslopes

- avoidance of storing water in dams on saline areas

- minimisation of cultivation on the floodplain

- redistribution of nutrients onto (is two words whereas into is one word) hill insert space here slopes and to the head of the floodplain

- grazing regime managed to promote a succession of pasture species from a dominance of less palatable annual broad-leaf species to a dominance of more palatable perennial grasses.

Such non-structural measures have the potential to provide increased pasture productivity, increased soil organic carbon levels, and increased residence time of nutrients. The improved ground cover and minimal cultivation helps minimise soil erosion, avoids soil compaction, and maintains soil structure.

\section{Implications}

These observations on the benefits of Natural Sequence Farming have significant implications for capacity building in relation to the management of Australian landscapes. It is critical for educators to impart techniques that enhance ecological resilience and sustainable productivity. Likewise, regulators should be encouraged to apply NSF principles as policy wherever possible.

\section{References}

Andrews, P. (2006) Back from the Brink: How Australia's Landscape can be Saved, ABC Books, Sydney.

Andrews, P. (2008) Beyond the Brink: A Radical Vision for Australia's Landscape, ABC Books, Sydney.

CSIRO (2002) The Natural Farming Sequence, CSIRO, Expert Panel Review, Canberra, http:// www.clw.csiro.au/publications/consultancy/2002/Tarywyn_Park_Upper_Bylong_Valley.pdf

Eyles, R.J. (1977) 'Changes in drainage networks since 1820', Australian Geographer, Vol. 13, pp.377-387.

Hughes, A.O., Prosser, I.P., Stevenson, J., Scott, A., Gallant, J. and Moran, C.J. (2001) Gulley Erosion Mapping for National Land and Water Resources Audit, CSIRO Land and Water, Technical Report26/01, Canberra. 
Southern Cross University (SCU) Restoring hydrological connectivity of surface and ground waters: Biogeochemical processes and environmental benefits for river landscapes, http://www.scu.edu.au/geoscience/index.php/12/

Young, W.J., Schiller, C.B., Harris, J.H., Roberts, J. and Hillman, T.J. (2001) 'River flow, processes, habitats and river life', in Young, W.J. (Ed.): Rivers as Ecological Systems: The Murray-Darling Basin, Murray-Darling Basin Commission, Canberra. 